\title{
The presence and distribution of high risk HPV types in simultaneous cervical cytology samples
}

\section{Eș zamanlı servikal sitoloji örneklerinde yưksek riskli HPV tiplerinin varlığı ve dağılımı}

\author{
Sibel AYDOĞAN¹', Aylin YAZGAN², Emre Erdem TAŞ , Ayşegül GÖZALAN¹, \\ Ayşe Filiz YAVUZ ${ }^{3}$, Ziya Cibali AÇIKGÖZ ${ }^{4}$
}

\begin{abstract}
Objective: Human papillomavirus (HPV) is the most detected viral pathogen of reproductive system and almost all servical carsinomas are related to HPV. The incidance and mortality rate of cervical carsinomas are significantly decrease by means of early diagnosis and treatment owing to servical cancer screening programmes. The aim of the study is to evaluate the results of HPV DNA tests and cervical cytology specimens simultaneously in a three year period.
\end{abstract}

Methods: The test results of 328 patients that were send to determine Molecular Microbiology Laboratory for HPV DNA and genotype between 2012-2014 were retrospectively analysed. Moreover, the cytology results of the same patient group were reviewed simultaneously by pathologist and reexamined if necessary. The relationship between cervical anomalies and the presence of HPV DNA and genotypes were exhibited. Cervical samples were collected in DigeneHC2 DNA Collection Device and DNA was isolated using QIAamp DNA Mini Kit. DNA samples were tested for high risk HPV infection by the Genotyping Kit HPV GP. Cytological examination were done by using conventional (Papanicolaou) method and interpreted according to 2001 Bethesda System.

\section{ÖZET}

Amaç: Human papillomavirus, reprodüktif sistemin en sık görülen viral enfeksiyon etkenidir ve neredeyse tüm serviks kanseri olgularılya ilișkisi gösterilmiștir. Servikal kanser tarama programları ile erken tanı ve tedavi sayesinde insidans ve mortalite oranları etkin șekilde azalmaktadır. Bu çalıșmada üç yıllık bir süre içinde çalıșılan HPV DNA test sonuçları ve eș zamanlı servikal sitoloji örneklerinin değerlendirilmesi amaçlanmıștır.

Yöntem: 2012-2014 yılları arasında Moleküler Mikrobiyoloji Laboratuvarı'na HPV DNA araștırılması ve genotip tayini amacıyla gönderilen 328 hastaya ait tesrt sonuçları retrospektif olarak analiz edilmiștir. Hastaların sitoloji sonuçları eș zamanlı olarak patoloji laboratuvarı tarafından retrospektif olarak değerlendirilmiş, gerek duyulan örnekler tekrar incelenerek servikal anormallikler ile HPV varlığı ve genotipler arasındaki ilișkiler ortaya konulmuștur. Servikal örnek alımında DigeneHC2 DNA Collection Device ${ }^{\circledR}$ kullanılmış ve DNA eldesi QIAamp ${ }^{\circledR}$ DNA Mini Kit ile yapılmıștır. DNA örneklerinde yüksek riskli HPV tiplerinin varlığı Genotyping Kit HPV GP kullanılarak araștırılmıștır. Sitolojik değerlendirme konvansiyonel Papanicolau testi ile yapılmıș ve sonuçlar 2001 Bethesda Sistemi'ne göre yorumlanmıștır.

'Department of Medical Microbiology, Ankara Ataturk Training and Research Hospital, Ankara

${ }^{2}$ Department of Pathology, Ankara Ataturk Training and Research Hospital, Ankara

${ }^{3}$ Department of Gynecology and Obstetrics, Faculty of Medicine, Yildirim Beyazit University, Ankara

${ }^{4}$ Department of Medical Microbiology, Faculty of Medicine, Yıldırım Beyazıt University, Ankara

İletişim / Corresponding Author : Sibel AYDOĞAN

Atatürk Eğitim ve Araştırma Hastanesi Eskişehir Yolu 2. Km Bilkent 06500 Ankara - Türkiye

Tel : +905336228508 E-posta / E-mail : drsaydogan72@gmail.com

Geliş Tarihi / Received : 29.07.2016 Kabul Tarihi / Accepted : 11.08 .2017

DOI ID : 10.5505/TurkHijyen.2018.15986

Aydoğan S, Yazhan A, Tas EE, Gözalan A, Yavuz AF, Açıkgöz ZC. The presence and distribution of high risk HPV types in simultaneous cervical cytology samples. Turk Hij Den Biyol Derg, 2018; 75(1): 13-20 
Results: The median age of the patients was found 36 and there was no significant difference between the median ages of the HPV DNA negative and positive women. High risk HPV DNA was determined 110 out of 328 patients (33.5\%) and multiple types were detected $22.7 \%$ of the cases. The most determined types were HPV-16/51/18 and 56 respectively. Abnormal cytology was detected from $21.5 \%$ of the 270 patients that were evaluated by pathologist simultaneously. The abnormal cytologic signs of the patients were reported as $48.3 \%$ ASCUS, $34.5 \%$ LSIL, 7\% ASC-H, 7\% HSIL and 3.5\% AGUS. The HPV DNA positivity of the patients with abnormal cytologic results (50\%) were found high significantly comparing the patients with normal cytology $(28.3 \%)(p=0.002)$. The type 16 was determined $38 \%$ and $44 \%$ from the patients with abnormal and normal cytology, respectively.

Conclusion: The genotyping of HPV plays an important role while the cervical cancer screening programmes have gaining importance globally. The determination of high rates of type 16 from patients with normal cytology proves that cytologic evaluation should be supported by DNA typing and those patients should be followed up closely.

Key Words: cervical cancer, cytology, high risk HPV

\section{INTRODUCTION}

Cervical cancer incidence varies very much from country to country. This difference is remarkable especially between developed and developing countries for the applicability of screening programs. The prevalence of cervical cancer ranks fourth all over the world but rises to second in developing countries (1). In 2012, 528.000 new cases and 266.000 mortality were reported and more than $85 \%$ of the cases were from low and middle income countries (2). In Turkey, cervical cancer was the ninth common cancer $(2.5 \%)$ in females for all ages but rised to fifth place in 25-49 age
Bulgular: Hastaların yaș ortancası 36 olup, test sonucu pozitif ve negatif kadınların yaș ortancaları arasında anlamlı fark bulunmamıștır. Yüksek riskli HPV DNA analizi yapılan 328 hastanın 110 tanesinde (\%33.5) pozitif sonuç elde edilmiș ve $\% 22.7$ oranında multiple tip varlığı bulunmuștur. En sık saptanan tipler HPV16/51/18/56 olarak belirlenmiștir. Hastaların 270'inde eș zamanlı sitolojik değerlendirme yapılmıș ve \%21.5 anormal sitoloji saptanmıștır. Anormal sitoloji saptanan hastaların sitolojik bulgulara göre dağılımı; \%48.3 ASCUS, \%34.5 LSIL, \%7 ASC-H, \%7 HSIL ve \%3.5 AGUS șeklinde olmuștur. Anormal sitoloji saptanan hastalardaki HPV pozitifliği (\%50), normal sitolojili hastalardaki HPV pozitifliğinden (\%28.3) istatistiksel olarak anlamlı derecede yüksek bulunmuștur ( $\mathrm{p}=0.002)$. Çalıșmamızda Tip 16, anormal sitolojili grupta \%38, normal sitolojili grupta ise \%44 oranında saptanmıștır.

Sonuç: Servikal kanser tarama programları tüm dünyada hızla önem kazanırken, HPV genotipleme önemli rol üstlenmektedir. Normal sitolojili hastalarda da Tip 16'nın yüksek oranda saptanması, sitolojik incelemenin mutlaka DNA çalıșması ile desteklenmesi ve hastaların yakın takibe alınması gerekliliğini kanıtlamaktadır.

Anahtar Kelimeler: servikal kanser, sitoloji, yüksek riskli HPV group (3.4\%) according to 2013 data (3).

Almost all cervical cancers are shown to be related to Human Papilloma Virus (HPV) genital infections. Although most of the HPV infections do not cause any symptoms or clinical situations and recovered spontaneously, chronic infections and precancerous lesions may develope into invasive cancers. This process takes many years in women with normal immunity system, but decreases to 5-10 years in immune compromised individuals. In this period, carcinogenesis can be mostly prevented by the 
determination of cytological atypia and treatment. As the tissue may be invaded by the virus before the determination of atypic cells, testing specific HPV is considered to be more effective for cancer prevention $(1,2,4)$.

Currently, more than 200 types of HPV are identified and classified as genital or oncogenic types according to their potentials $(5,6)$. Because of the limitations of the serological tests and the impossibility of virus culture, molecular tests are preferred for microbiological identification of HPV. Nowadays, molecular tests have been widely used for screening, diagnosing and follow-up after treatment $(7,8)$.

HPV prevalence changes according to the community, age, and the sensitivity and specificity of the testing method. The true numbers cannot be determined as the infections are mostly temporary. Several studies were made about the presence and identification of HPV DNA and its relationship with cervical pathologies in all world and also in Turkey. The data of our hospital between 2006-2010 was shared in a multi-centered investigation (9). The aims of the study were to determine the presence and distribution of high risk HPV types in cervical cytology specimens between 2012-2014 and to evaluate the differences of HPV types in samples with normal and abnormal cytology.

\section{MATERIAL and METHOD}

The test results of 328 patients sent to molecular microbiology laboratory of our hospital for HPV DNA and genotyping between 2012-2014 were retrospectively analyzed. The cytology results of the patients were reviewed simultaneously by pathology laboratory and reexamined if necessary. The relationship between cervical anomalies and the presence of HPV DNA and genotypes were evaluated.

The study was approved by the Clinical Trials Ethics Committee of Yıldırım Beyazıt University
Medical Faculty (16.09.2015/180).

HR-HPV testing: Cervical samples were collected in DigeneHC2 DNA Collection Device ${ }^{\circledR}$ (Qiagen, Germany) and DNA was isolated using QIAamp DNA Mini Kit (Qiagen) according to manufacturer's instructions from cervical samples. DNA samples were tested for HR-HPV infection by the Genotyping Kit HPV GP (Diassay BV, The Netherlands) as described previously (10). Principle of the test is based on the reverse hybridization of amplicons obtained by PCR of extracted DNA. The kit identifies $18 \mathrm{HR}$ genotypes $(16,18,26,31,33,35,39,45,51,52,53,56,58,59$, $66,68,73,82)$.

Cytological evaluation: Conventional (Papanicolaou Technique) smears were evaluated cytologically according to the Bethesda System 2001.

Statistical analysis: Statistical analysis was performed using IBM SPSS Statistics (version 20.0). Visual and analytical methods were used (Kolmogorov-Smirnov test) to determine whether the variables were normally distributed or not. Non-normally distributed variables were described using the median and the interquartile range (IQR). Pearson's x2test and the Mann-Whitney $U$ test were used to analyze the data, as appropriate. $\mathrm{P}<0.05$ was considered to be statistically significant.

\section{RESULTS}

High risk HPV DNA was determined in 110 of 328 patients (33.5\%), while multiple types were identified in $22.7 \%$ of the cases. The positive HPV DNA rates were found $20 \%(8 / 40), 31 \%(34 / 110)$ and $38.2 \%(68 / 178)$ in 2012, 2013 and 2014 respectively. The median age of all patients was found 36 (IQR=16, range:19-69). The median age of HPV DNA positive and negative patients was (34.5, IQR=18) and (37, IQR=16) respectively and there was no statistically significant difference between them $(p=0.295)$. 
Table 1. Distribution of the HR-HPV types

\begin{tabular}{|c|c|c|}
\hline \multirow{2}{*}{ Types } & \multicolumn{2}{|c|}{ HPV-positive $(n=110)$} \\
\hline & $\mathrm{n}$ & $\% *$ \\
\hline 16 & 46 & 41.8 \\
\hline 51 & 14 & 12.7 \\
\hline 18 & 13 & 11.8 \\
\hline 56 & 11 & 10.0 \\
\hline 31 & 8 & 7.3 \\
\hline 58 & 8 & 7.3 \\
\hline 59 & 8 & 7.3 \\
\hline 52 & 7 & 6.4 \\
\hline 66 & 6 & 5.5 \\
\hline 33 & 5 & 4.5 \\
\hline 45 & 5 & 4.5 \\
\hline 35 & 3 & 2.7 \\
\hline 39 & 3 & 2.7 \\
\hline 53 & 2 & 1.8 \\
\hline 68 & 2 & 1.8 \\
\hline 82 & 1 & 0.9 \\
\hline Multiple & 25 & 22.7 \\
\hline
\end{tabular}

* row percentage

The most determined types were $16(41.8 \%), 51$ (12.7\%), 18 (11.8\%) and 56 (10\%). Multiple types were detected from 25 (22.7\%) HPV positive women (Table 1).

Abnormal cytology was detected from 50 $(21.5 \%)$ out of 270 patients that were evaluated by pathologists simultaneously. The abnormal cytologic signs of the patients were reported as $48.3 \%$ ASCUS, $34.5 \%$ LSIL, 7\% ASC-H, 7\% HSIL and 3.5\% AGUS. The HPV DNA positivity $(50 \%)$ of the patients with abnormal
Table 2. Cervical cytology versus HPV status

\begin{tabular}{|c|c|c|c|c|c|}
\hline \multirow{2}{*}{ Cytology } & \multicolumn{2}{|c|}{ HPV-negative } & \multicolumn{2}{|c|}{ HPV-positive } & \multirow{2}{*}{$\begin{array}{c}p \\
\text { value }\end{array}$} \\
\hline & $\mathrm{n}$ & $\%$ & $\mathrm{n}$ & $\%$ & \\
\hline $\begin{array}{l}\text { Normal } \\
\text { cytology } \\
(n=212)\end{array}$ & 152 & 71.7 & 60 & 28.3 & 0.002 \\
\hline $\begin{array}{l}\text { Anormal } \\
\text { cytology } \\
(n=58)\end{array}$ & 29 & 50 & 29 & 50 & \\
\hline ASCUS $(n=28)$ & 17 & 60.7 & 11 & 39.3 & \\
\hline ASC-H $(n=4)$ & 1 & 25 & 3 & 75 & \\
\hline LSIL $(n=20)$ & 9 & 45 & 11 & 55 & \\
\hline HSIL $(n=4)$ & 1 & 25 & 3 & 75 & \\
\hline AGUS $(n=2)$ & 1 & 50 & 1 & 50 & \\
\hline
\end{tabular}

cytological results were found high significantly comparing to the patients with normal cytology (28.3\%) ( $p=0.002)$ (Table 2).

The types of HR-HPV positive patients with abnormal cytopathologies were $16(38 \%), 18(13.8 \%)$, $51(13.8 \%), 33(10.3 \%), 56(10.3 \%), 58(10.3 \%), 31$ (7\%), 45 (7\%), 53 (7\%), 59 (7\%), 66 (7\%), $68(7 \%), 35$ (3.5\%), $39(3.5 \%)$ and $52(3.5 \%)$, respectively. The $34.5 \%$ of the patients had 2-4 multiple HPV types (Table 3).

Sixty $(28.3 \%)$ of 212 patients with normal cytopatologic results were determined as HR-HPV DNA positive. Forty-nine patients had only one type and 11 (18.3\%) patients had 2-3 multiple HPV types in the study. The most determined types were $44 \%$ Type 16, 15.3\% Type 51, 12\% Type 56 and 10.2\% Type 18 (Figure 1). 
Table 3. HPV types of patients with abnormal cytology

\begin{tabular}{|c|c|c|c|c|c|}
\hline & \multicolumn{5}{|c|}{ Cytology } \\
\hline & $\begin{array}{l}\text { ASCUS } \\
(n=11)\end{array}$ & $\begin{array}{c}\text { LSIL } \\
(n=11)\end{array}$ & $\begin{array}{c}\text { ASC-H } \\
(n=3)\end{array}$ & $\begin{array}{c}\text { HSIL } \\
(n=3)\end{array}$ & $\begin{array}{l}\text { AGUS } \\
(n=1))\end{array}$ \\
\hline & 16 & 16 & 16 & 16 & 51 \\
\hline & 16 & 16 & 33 & 16,39 & \\
\hline & 18 & 18 & 45 & 16,51 & \\
\hline \multirow[t]{8}{*}{ Types } & 35 & 18 & & & \\
\hline & 56 & 56 & & & \\
\hline & 66 & 66 & & & \\
\hline & 16,56 & 16 & & & \\
\hline & 33 & 31,68 & & & \\
\hline & 45,59 & 33,58 & & & \\
\hline & 16,53 & $18,31,58$ & & & \\
\hline & $51,53,58,59$ & $51,52,68$ & & & \\
\hline
\end{tabular}

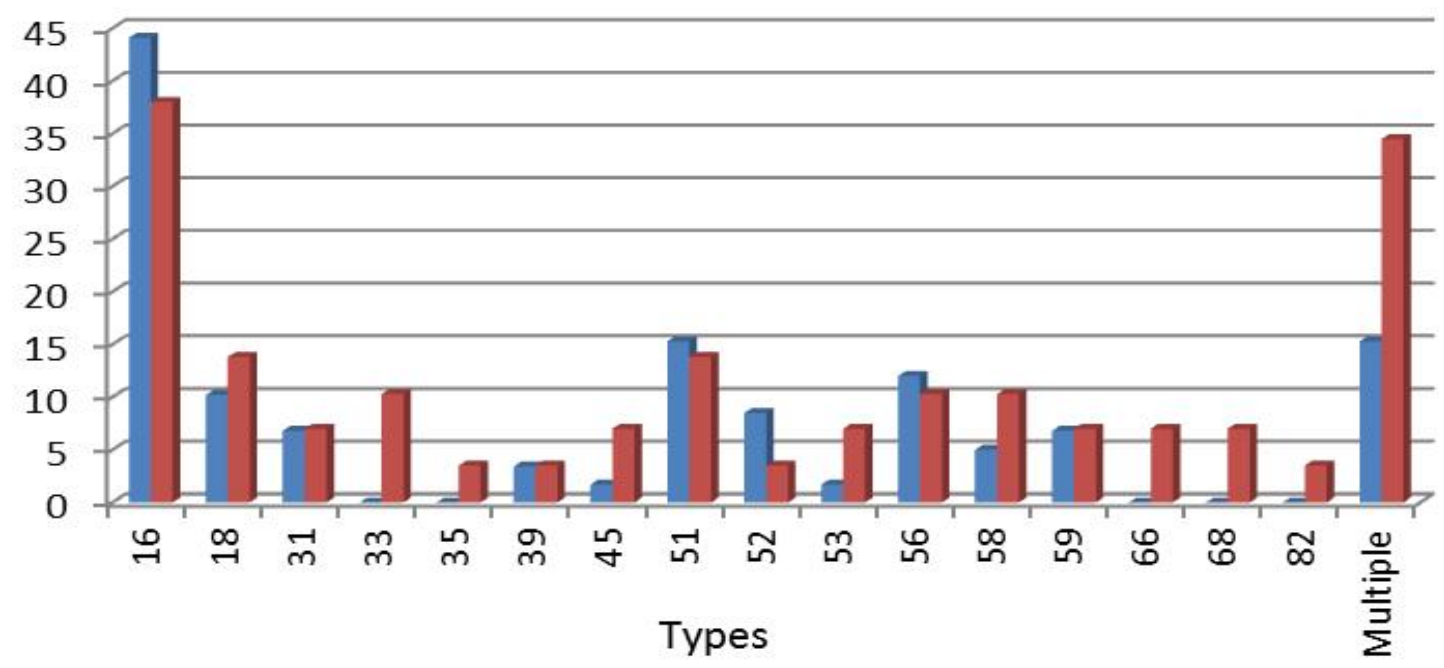

\% In normal cytology — \% In anormal cytology

Figure 1. Accuracy test results of anti-endomysium and anti-gliadin IgA IFAT 


\section{DISCUSSION}

Cervical cancer screening tests are performed in the healthy looking women with no symptoms for determining precancerous and cancerous lesions. Precancerous lesion development takes years so at least one, ideally more cervical cancer screening tests are recommended for every woman between 30-49 years old in the life time (2).

In developed countries, most of the precancerous lesions are diagnosed in curable period by screening programmes and $80 \%$ of the cervical cancers are prevented by early therapy.

Unfortunately, in developing countries diagnosing of the cancer is delaying until advanced stages and the occurrence of the symptoms. Besides, therapies are usually insufficient in the advanced stages and eventually mortality rates rise (11). There are three types of screening tests at the present time: Conventional Papanicolaou (PAP) smears and liquidbased cytology, visual inspection with acetic acid and/ or lugol's iodine (VIA/VILI), investigation of HR-HPV types. Cytological screening (PAP-smears) are the most common and the oldest tests. Although this technique decreases the incidence and mortality effectively in most of the developed countries, same progress cannot be reached in developing countries. Multiple testing is required for the success of cytology-based screening. However, routine screening cannot be done because of the reasons like socio-cultural structure and lack of knowledge in developing countries. Also, $50 \%$ of the high grade lesions and carcinomas remain unnoticed by one time screening $(1,6,12)$.

VIA/VILI is a simple and easy method which does not need high technology. As there is a possibility of misevaluation of cervix degeneration and transitional zone especially in women over 40 years old, VIA/VILI usage is limited. (1).

Nowadays, a lot of high specific and sensitive HPV tests have been developed and used widely for primary cancer screening. $(5,8)$.

Cervical cancer screening program has recently been begun in Turkey. Therefore, even multi-centered studies do not represent the real prevalence of HPV infections. Besides, there are various research results depending on not only the regional and socio-cultural differences but also the cause of hospital admission and the selection of the study group. In a twelvecentered study which also included the results our hospital, HPV positivity was reported as $27 \%$, $57 \%$ and $25 \%$ in patients with normal cytology, abnormal cytology and all patients between 2006-2010, respectively (9).

In the present study, data between 2012 and 2014 were evaluated and HPV positivity was found $33.5 \%$. There was a progressive increase by years as $20 \%, 31 \%$ and $38.2 \%$. The test choice of the clinicians, the cause of patients' admission and raise of awareness in society were thought to be reasons of this trend. In the last five-year period, a wide distribution of HPV positivity (\%4-69.6) was reported from different regions in Turkey (Table 4) (13-20). The variations may be caused from the regions, the characteristics of the study group or different test methods. The most detected HR-HPV type was 16 in Turkey similar to the studies from the world (Table 4). Type 16 was also the most determined type (41.8\%) in the present study followed by the types 51, 18, 56 and 31. A different type of distribution was reported by Yuce et al.; type 16 was followed by 31, 51, 33 and 52 and type 18 was found at the sixth place (14).

Multiple types of HR-HPV were detected from $22.7 \%$ of the women infected by HPV in our study likewise other researches from Turkey (1.1-37\%) (Table 4). The effect of infection with multiple genotypes is not clear. There are opposite results about synergistic influences on oncogenesis reported in several studies. Salazar et al. reported that HRHPV infection had more risk for high grade lesions and there was no additive or synergic activity associated with the presence of infections with different high or low risk combinations. It was suggested that infections with multiple types trigger local or humoral immunity response more effective than one type (21). 
Table 4. Results of HPV studies reported from Turkey published between 2010-2015

\begin{tabular}{|c|c|c|c|c|c|}
\hline Author and reference number & $\mathrm{n}$ & $\begin{array}{c}\text { HPV positive* } \\
\%\end{array}$ & $\begin{array}{c}\text { Multiple types ** } \\
\%\end{array}$ & $\begin{array}{c}\mathrm{HR}-\mathrm{HPV} \\
\%\end{array}$ & $\begin{array}{c}\text { Type } 16^{* *} \\
\%\end{array}$ \\
\hline Eren et al. (13) & 500 & 16.5 & 35.8 & 75 & 34 \\
\hline Yuce et al. (14) & 890 & 25.7 & 23.6 & 89.5 & 46.3 \\
\hline Akyar et al. (15) & 1014 & 69.6 & NA & 47.7 & 14.2 \\
\hline Akcali et al. (16) & 410 & 8.5 & 37.1 & 65.7 & 28.5 \\
\hline Dursun et al. (17) & 403 & 23 & NA & NA & 34 \\
\hline Ozalp et al. (18) & 615 & 4 & NA & NA & 46.1 \\
\hline Altun et al. (20) & 460 & 5.2 & 1.1 & 58.3 & 33.3 \\
\hline
\end{tabular}

The abnormal cytology rate was $21.5 \%$ in our study. Human papillomavirus was determined $50 \%$ and $27.8 \%$ from the patients with abnormal and normal cytology respectively. Akyar et al. found HPV positivity $75.1 \%$ in cytology positive and $63 \%$ in cytology negative patients (15). Cervical cytology abnormality rate was reported as $1.8 \%$ according to the data of our country (19). The high cytology abnormality rate of our study may be resulted from the study type as it is a training and research hospital based research. As it is known, types $16 / 18$ are responsible from $70 \%$ of the cervical cancers while types $31 / 33 / 45 / 52 / 58$ are determined only in $20 \%$ of the cancers. A recently developed 9-valent vaccine targeted not only 6/11/16/18 types but also $31 / 33 / 45 / 52 / 58$ types. (22). In Turkey, HPV vaccination is limited. Insufficiency of screening programs, the cost of the vaccines and uncertainty of the target population are the reasons of the situation. It is indicated that vaccination before the start of sexual activity gain more success independent of the screening programs (23).

Genotyping of HPV plays an important role in new publications as the cervical cancer screening programmes are gaining importance globally. Some guidelines suggested only HPV test without cytological examination for women over 25 years old, triennially. For determining cervical precancerous lesions, HPV test is more sensitive than cytology and less affected by sampling procedures. (5). Type 16 was detected $38 \%$ and $44 \%$ in the abnormal and normal cytology groups in the present study. The high rate of HR-HPV indicates the importance of close follow-up of the women with normal cytology.

In conclusion; although the cervical cancer incidence is low in our country, there are big differences among the HPV positivity rates. Serious consequences and precautions should be taken. The studies about the efficiency of the cervical cancer screening program and HPV vaccination process have been gaining accelerate in Turkey. The high rate of HR-HPV in this study indicates the importance of close follow-up of the women with normal cytology. Besides, as our training and research hospital has many admissions from various cities, this study results may contribute to HPV data of Turkey. 


\section{REFERENCES}

1. Catarino R, Petignat P, Dongui G, Vassilakos P. Cervical cancer screening in developing countries at a crossroad: Emerging Technologies and policy choices. World J Clin Oncol 2015; 6(6):281-90.

2. World Health Organization. Human papillomavirus (HPV) and cervical cancer. Reviewed March 2015. Available from: URL: http://www.who.int/ mediacentre/factsheets/fs $380 / \mathrm{en} /$.

3. T.C. Saglik Bakanligi, Turkiye Halk Sagligi Kurumu, Turkiye Kanser Istatistikleri Ankara 2016. URL: http: // kanser.gov.tr/Dosya/ca_istatistik/ANA_ rapor_2013v01_2.pdf.

4. Egawa N, Egawa K, Griffin H, and Doorbar J. Human papillomaviruses; epithelial tropisms. and the development of neoplasia. Viruses 2015; 7:3863-90.

5. McGraw SL, Ferrante JM. Update on prevention and screening of cervical cancer. World J Clin Oncol 2014;5(4):744-52.

6. Choi YJ, Park JS. Clinical significance of human papillomavirus genotyping. J Gynecol Oncol. 2016; 27(2):e21.

7. Sahiner F. Current problems and recent advances in the molecular diagnosis of genital human papillomavirus infections. Mikrobiyol Bul 2014; 48(4):689-706.

8. Abreu ALP, Souza RP, Gimenes F, Consolaro MEL. A review of methods for detect human papillomavirus infection. Virology Journal 2012;9:262.

9. Dursun P, Ayhan A, Mutlu L et al. HPV types in Turkey: multicenter hospital based evaluation of 6388 patients in Turkish gynecologic oncology group centers. Turk Patoloji Derg 2013; 29(3):210-16.

10. Fongmoon D, Nakong M, Lalitwongsa S, Keyoonwong W. Prevalance and genotypic distribution of high risk humanpapillomavirus infection among women screened for cervical cancer at Lampang Cancer Hospital. Bull Chiang Mai Assoc Med Sci 2015; 48(3):231-40.

11. Sankaranarayanan R. Screening for cancer in low and middle income countries. Annals of Global Health 2014; 80:412-17.

12. Zong LJ, Zhang $Y-Z$, Yang $X-S$, Jiang J, Cui B-X, Qiao Y-B, et al. Evaluation of several screening approaches for detection of cervical lesions in rural Shandong, China. Asian Pac J Cancer Prev 2015; 16(5):1907-12.
13. Eren $F$, Erenus $M$, Bas E, Ahiskali R, Yoldemir $T$. Prevalance of HPV infection by cytologic diagnosis and HPV DNA extraction and prevalance of the HPV genotypes detected in urban Turkish women. Int J Gynecol Obstet 2010; 109:235-38.

14. Yuce K, Pinar A, Salman MC, Alp A, Sayal B, Dogan $S$, Hascelik G. Detection and genotyping of cervical HPV with simultaneous cervical cytology in Turkish women: a hospital based study. Arch Gynecol Obstet 2012; 286:203-8.

15. Akyar I, Aydın O, Yakicier MC, Kocagoz ZT, Ince U, Unsal I. Human papillomavirus prevalance and type in liquid-based cervical samples from Turkish women in a selected risk group. Turk J Med Sci 2013; 43:963-70.

16. Akcali S, Goker A, Ecemis T, Kandiloglu AR, Sanlidag T. Human papillomavirus frequency and genotype distribution in a Turkish population. Asian Pacific J Cancer Prev; 2013; 14(1):503-6.

17. Dursun P, Senger SS, Arslan H, Kuscu E, and Ayhan A. Human papillomavirus (HPV) prevalance and types among Turkish women at a gynecology outpatient unit. BMC Infect Dis 2009; 9:191.

18. Ozalp S, Us T, Arslan E, Oge T, Kasifoglu N. HPV DNA and Pap smear results in cases with and without cervical pathology. J Turkish-German Gynecol Assoc 2012; 13:8-14.

19. Turkish Cervical Cancer and Cervical Cytology Research Group. Prevalance of cervical cytological abnormalities in Turkey. Int J Gynecol Obstet 2009; 106:206-9.

20. Altun Z, Yarkın F, Vardar MA, Uguz AH. The prevalance of human papillomavirus infection among women who admitted to Çukurova University Faculty of Medicine Hospital. Turkiye Klinikleri J Med Sci 2011; 31(2):307-14.

21. Salazar KL, Zhou HS, Xu J., Peterson LE, Schwartz MR, Mody DR, Ge Y. Multiple human papillomavirus infections and their impact on the development of high-risk cervical lesions. Acta Cytologica 2015; 59:391-98.

22. Nakalembe M, Mirembe FM, Banura C. Vaccines against human papillomavirus in low and middle income countries: a review of safety, immunogenicity and efficacy. Infect Agent Cancer 2015; 10:17.

23. Dede M. Profilaktik HPV așıları: güncel yaklașımlar. Gülhane Tıp Derg 2010; 52:148-56. 